\title{
ВАЛЮТНЫЙ КОНТРОЛЬ В СИСТЕМЕ ОБЕСПЕЧЕНИЯ ЭКОНОМИЧЕСКОЙ БЕЗОПАСНОСТИ ГОСУДАРСТВА
}

\author{
(c) 2019 Ростовщикова Елена Евгеньевна \\ аспирант кафедры таможенного дела \\ Тюменский государственный университет, Россия, Тюмень \\ E-mail: rostovshchikovaee@gmail.com
}

В статье рассмотрены основные угрозы и риски экономической безопасности государства в области валютного контроля. Определено, что основными направлениями валютного контроля в Российской Федерации являются проведение органами валютного контроля проверок соблюдения валютного законодательства по внешнеторговым контрактам и противодействие легализации доходов, полученных преступным путем. Актуальность темы обусловлена сохранением высоких объемов сомнительных валютных операций, а также многообразием каналов незаконного вывода денежных средств с территории Российской Федерации.

Ключевые слова: Валютный контроль, проверки соблюдения валютного законодательства, сомнительные валютные операции, легализация преступных доходов, курьеры наличных.

В условиях высоких объемов внешнеторговой деятельности российских предприятий важнейшей функцией государства в рамках обеспечения экономической безопасности является обеспечение безопасности в сфере валютных отношений. При этом основным направлением защиты государственных интересов в сфере валютных отношений является валютный контроль за соблюдением резидентами законодательства при исполнении обязательств по внешнеторговым контрактам, а также противодействие легализации доходов, полученных преступным путем.

Валютный контроль в Российской Федерации осуществляется Центральным банком, таможенными и налоговыми органами, а также коммерческими организациями - уполномоченными банками.

Контролю со стороны указанных органов подлежит исполнение российской стороной обязанностей, предусмотренных положениями Федерального закона от 10.12.2003 № 173-Ф3 «О валютном регулировании и валютном контроле» (далее - Закон), Инструкции Банка России от 16.08.2017 № 181-И «О порядке представления резидентами и нерезидентами уполномоченным банкам подтверждающих документов и информации при осуществлении валютных операций, о единых формах учета и отчетности по валютным операциям, порядке и сроках их представления» (далее - Инструкция), а именно обязанностей:
- по обеспечению получения на свои банковские счета в предусмотренные контрактом сроки валютной выручки, причитающейся за отправленный иностранной стороне товар (пункт 1 части 1 статьи 19 Закона);

- по обеспечению в контрактный срок возврата авансовых платежей, уплаченных за непоставленный контрагентом товар (пункт 2 части 1 статьи 19 Закона);

- по представлению в уполномоченный банк предусмотренных законодательством документов, связанных с проводимыми валютными операциями (положения Инструкции).

Система осуществления валютного контроля в Российской Федерации действует следующим образом. В соответствии с Указанием Банка России от 16.08.2017 № 4498-У уполномоченные банки, осуществляя контроль за проводимыми резидентами валютными операциями по внешнеторговым контрактам, в случае выявления нарушения валютного законодательства передают информацию с признаками предполагаемых нарушений в соответствующее территориальное подразделение Центрального Банка России. Накопленная информация о возможных нарушениях валютного законодательства передается Центральным Банком в зависимости от компетенции в ФТС и ФНС России, далее - в региональные управления, таможни и налоговые инспекции с целью проведения последними проверок по признакам предполагаемых нарушений валютного законодательства. 
Таможенные и налоговые органы в свою очередь могут обнаруживать признаки возможного несоблюдения российскими лицами требований валютного законодательства в инициативном порядке - на основании данных, имеющихся в информационных системах и общедоступных источниках. При этом компетенция органов разделена следующим образом: таможенные органы проводят проверочные мероприятия по внешнеторговым контрактам, предусматривающим экспорт/импорт товаров, налоговые органы - по контрактам, связанным с выполнением работ, оказанием услуг.

Данные итогов деятельности ФТС и ФНС России за последние годы свидетельствуют о положительной динамике показателей по направлению валютного контроля (Рис. 1).

Так, количество проведенных таможенными и налоговыми органами проверок соблюдения валютного законодательства увеличилось в 2017 году в сравнении с 2016 годом в 1,6 раза, количество возбужденных дел возросло в 3,2 раза. Подобная положительная динамика обусловлена наделением в апреле 2016 года ФТС и ФНС России функциями органов валютного контроля, что подразумевает выполнение ими полномочий от выбора объектов валютного контроля до взыскания штрафов за выявленные административные правонарушения.

Стоит отметить, что основными нарушениями, выявляемыми таможенными и налоговыми органами по результатам проверок в 2017 году, являлись нарушения, связанные с несоблюдением установленного порядка или срока представления форм учета по валютным операциям. На данные правонарушения приходилось 85\% возбужденных дел об административных правонарушениях [1].

Однако наибольшую опасность для экономики государства представляют нарушения валютного законодательства, на долю которых приходится не более $15 \%$ от общего объема - нарушения, принимающие форму непоступления валютной выручки по экспортным контрактам, а также невозврата осуществленных платежей за непоставленный товар по импортным контрактам. В 2017 году по результатам рассмотрения дел, связанных с нерепатриацией денежных средств, налоговыми органами предъявлено штрафных санкций на сумму 179,5 млн. рублей, таможенными органами выявлены случаи невозврата на территорию государства денежных средств в сумме более 24 млрд. рублей [3].

Эффективной формой проведения контрольных мероприятий в сфере валютного контроля являются скоординированные проверочные мероприятия таможенных и налоговых органов, предполагающие всесторонний анализ внешнеторговых контрактов, предусматривающих одновременно и перемещение товаров, и оказание услуг/выполнение работ. В 2018 году таможенными и налоговыми органами проведено 36 скоординированных проверочных мероприятий [8], что в 2,4 раза превышает значение показателя прошлого года (в 2017 году - 15 скоординированных проверочных мероприятий), по результатам которых возбуждено 45 дел об административных правонарушениях в области валютного законодательства (в 2017 году - 20 дел).

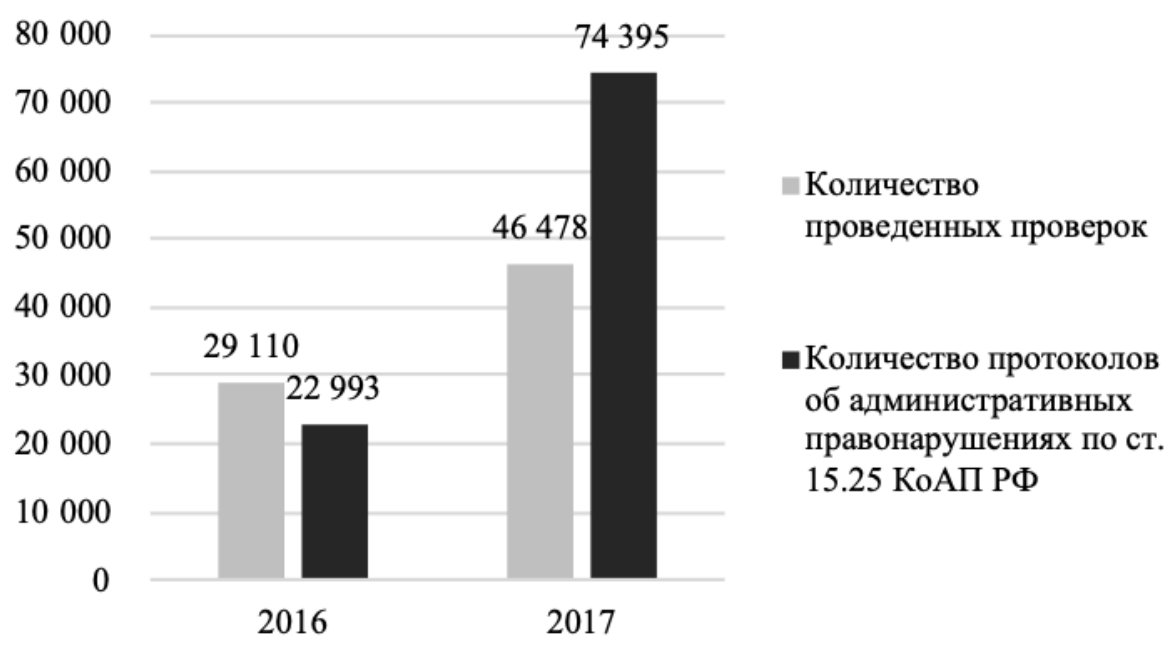

Рис 1. Показатели деятельности ФНС и ФТС России по направлению валютного контроля в 2016-2017 гг.

Источник: составлено автором на основе данных об итогах деятельности ФТС [3] и ФНС России [2] 
Кроме осуществления контроля за проводимыми валютными операциями таможенные, налоговые органы и уполномоченные банки осуществляют функции по противодействию легализации доходов, полученных преступным путем. Особую роль при этом играет межведомственное взаимодействие с Федеральной службой по финансовому мониторингу (Росфинмониторинг).

В соответствии с данными Росфинмониторинга серьезную угрозу в области легализации преступных доходов представляет деятельность номинальных юридических лиц («фирм-однодневок»). Проведение операций по незаконному перемещению доходов через такие фирмы обусловлено особенностями законодательства в части доступности регистрации предприятий и наличия возможности учредить неограниченное количество организаций, а также свободой формирования сторонами условий внешнеторгового контракта в части выбора схемы оплаты. Риск представляют случаи, когда недобросовестная организация осуществляет в адрес нерезидента крупные авансовые платежи, не получая при этом товар в счет переведенных денежных средств и прекращая свою деятельность.

С целью минимизации масштабов деятельности «фирм-однодневок» налоговыми органами проводится работа по проверке достоверности сведений, указанных в отношении предприятий в Едином государственном реестре юридических лиц (далее - ЕГРЮЛ). В случае подтверждения в результате проверки недостоверности заявленных сведений (например, в отношении адреса регистрации юридического лица), налоговыми органами принимается решение об его исключении из ЕГРЮЛ. Так, с 2016 года по июнь 2018 года из ЕГРЮЛ исключено около 1 млн. юридических лиц [5, с. 20].

Кроме того, на постоянной основе осуществляется информационное взаимодействие между ФНС, ФТС России и кредитными организациями, целью которого является принятие мер об отказе в проведении валютной операции в случае подозрения на ее осуществление от имени «фирмы-однодневки». Совместная работа Росфинмониторинга с правоохранительными органами позволяет выявлять и производить арест уже выведенных за рубеж денежных средств. В 2017 году на основании материалов Росфинмониторинга о сомнительных валютных операциях арестовано за рубежом незаконно выведен- ных активов на сумму около 10 млрд. рублей [5, c. 21].

Наряду с угрозой вывода денежных средств «фирмами-однодневками» риск для экономической безопасности государства несет возможность использования участников рынка ценных бумаг и страхового сектора в схемах легализации преступных доходов. Для минимизации данного риска Центральным Банком России проводится «очистка» банковского сектора от недобросовестных участников. Так, в 2017 году аннулировано более 60 лицензий профессиональных участников рынка ценных бумаг (из них 13 - в связи с нарушениями законодательства), отозваны лицензии у 162 страховых организаций. Принятие подобных мер позволило сократить объем подозрительных валютных операций, то есть операций, не имеющих явного экономического смысла, на 24\%: с 96 млрд. рублей в 2017 году до 73 млрд. рублей в 2018 году [1].

Необходимо отметить, что одним из возможных каналов легализации доходов, полученных преступным путем, является незаконное перемещение физическими лицами наличных денежных средств, которое в соответствии с положениями Таможенного кодекса Евразийского экономического союза осуществляется без ограничений с обязанностью письменного декларирования в случае, если сумма перемещаемых наличных денежных средств и (или) дорожных чеков превышает в эквиваленте 10 тыс. долл. США.

Контроль за перемещением через границу Евразийского экономического союза наличных денежных средств входит в обязанности таможенных органов Российской Федерации. По данным Управления торговых ограничений, валютного и экспортного контроля ФТС России в последние годы наблюдается тенденция роста объема декларируемой перемещаемой валюты и снижения объема незаконно перемещаемых физическими лицами наличных денежных средств (в 2017 году по сравнению с 2016 годом в 1,57 раза: с 222 млн. рублей до 141 млн. рублей). Однако в связи с тем, что в соответствии с законодательством физическому лицу не требуется представлять каких-либо подтверждающих документов о происхождении денежных средств и целях их дальнейшего использования, по-прежнему сохраняется опасность существования так называемых «курьеров наличных» [4, с. 50]. Такие курьеры зачастую не являются владельцами пе- 
ремещаемых денежных средств, а сама перевозка связана с отмыванием преступных доходов, с ввозом/вывозом валюты от нелегальных внешнеторговых операций и пр. По данным Росфинмониторинга наиболее рисковыми направлениями незаконного ввоза/вывоза наличных денежных средств в современном мире остаются Турция, Китай и ОАЭ.

Подводя итоги, отметим, что в настоящее время валютный контроль является важнейшей составляющей в системе обеспечения экономической безопасности государства. Деятельность государственных органов и уполномоченных банков в рамках данного вида контроля направлена не только на выявление нарушений валютного законодательства в связи с исполнением российскими лицами обязательств по внешнеторговым контрактам, но и на пресечение совершения сомнительных валютных операций, представляющих собой угрозу в виде незаконного вывода капитала за рубеж. В связи с ограниченной компетенцией каждого органа в сфере валютного контроля серьезную роль играет межведомственное взаимодействие, позволяющее оперативно выявлять участников внешнеэкономической деятельности с признаками ненадежности и пресекать их недобросовестные намерения в рамках внешнеторговой деятельности.

\section{Библиографический список}

1. В 2018 году объем средств, выведенных из РФ за рубеж через сомнительные операции, уменьшился на 24\% - ЦБР [Электронный ресурс] URL: http://www.finmarket.ru/currency/news/4957339 (дата обращения 14.03.2019)

2. Доклад об осуществлении Федеральной налоговой службой государственного контроля (надзора) в соответствующих сферах деятельности и об эффективности такого контроля (надзора) в 2017 году [Электронный ресурс] URL: https://vk.com/away.php?to=https\%3A\%2F\%2Fwww.nalog.ru\%2Fhtml\%2Fsites\%2Fwww.new. nalog.ru\%2Fdocs\%2Fkontrol\%2Fdocladnadzor2017.docx\&cc_key= (дата обращения 10.03.2019)

3. Итоговый доклад о результатах и основных направлениях деятельности ФТС России в 2017 году [Электронный ресурс] URL: http://www.customs.ru/index.php?option=com_content\&view=article\&id=26323:-2017\&catid=475:2015-03-12-09-57-15\&Itemid=2588 (дата обращения 25.02.2019)

4. Медведенко О.В. Роль таможенных органов в обеспечении экономической безопасности России при осуществлении валютного контроля // Таврический научный обозреватель. - 2017. — № 1(18). - C. 47-52.

5. Национальная оценка рисков легализации (отмывания) преступных доходов. 2018. Основные выводы [Электронный ресурс] URL: http://www.fedsfm.ru/content/files/documents/2018/оценка\%20рисков\%20од_5. pdf (дата обращения 05.03.2019)

6. валютном регулировании и валютном контроле. Федеральный закон от 10.12.2003 № 173-ФЗ [Электронный ресурс] // СПС «КонсультантПлюс». URL: http://www.consultant.ru/document/cons_doc_LAW_45458/ (дата обращения 20.01.2019)

7. п противодействии легализации (отмыванию) доходов, полученных преступным путем, и финансированию терроризма. Федеральный закон от 07.08.2001 № 115-Ф3 [Электронный ресурс] // СПС «КонсультантПлюс». URL: http://www.consultant.ru/document/cons_doc_LAW_32834/ (дата обращения 20.01.2019)

8. Проект итогового доклада о результатах и основных направлениях деятельности ФТС России в 2018 году [Электронный ресурс] URL: http://www.customs.ru/index.php?option=com_content\&view=article\&id=27216:2018- \&catid=475:2015-03-12-09-57-15\&Itemid=2588 (дата обращения 15.03.2019)

9. Стрункин А.В. Взаимодействие Федеральной таможенной службы с другими органами валютного контроля РФ [Электронный ресурс] URL: https://forum-nauka.ru/domains_data/files/19/Strunkin\%20A.V.\%20-2.pdf (дата обращения 20.02.2019) 